\section{Kidney \\ Blood Pressure Research}

Original Paper
Kidney Blood Press Res 2014;39:516-525

DOI: $10.1159 / 000368462$
Publisned ontIne: November 29, 2014

C 2014 S. Karger AG, Basel

www.karger.com/kbr

1423-0143/14/0396-0516\$39.50/0

Accepted: October 08, 2014

This is an Open Access article licensed under the terms of the Creative Commons AttributionNonCommercial 3.0 Unported license (CC BY-NC) (www.karger.com/OA-license), applicable to the online version of the article only. Distribution permitted for non-commercial purposes only.

\title{
Upregulation of the Creatine Transporter Slc6A8 by Klotho
}

\author{
Ahmad Almilajia Mentor Sopjania,c Bernat Elvira ${ }^{a} \quad$ José Borras ${ }^{a}$ \\ Miribane Dërmaku-Sopjani ${ }^{\mathrm{a}, \mathrm{d}}$ Carlos Munoz ${ }^{\mathrm{a}} \quad$ Jamshed Warsi ${ }^{\mathrm{a}} \quad$ Undine E. Lang $^{\mathrm{b}}$ \\ Florian Langa \\ aDepartment of Physiology, Gmelinstr. 5, University of Tübingen, D-72076 Tübingen, Germany; \\ ${ }^{b}$ Department of Psychiatry, University Hospital Basel, Switzerland; 'Faculty of Medicine, University of \\ Prishtina, Str. Bulevardi i Dëshmorëve; dDepartment of Chemistry, University of Prishtina, Str. 'Nëna \\ Terezë' p.n. 10000 Prishtina, Kosova
}

\author{
Key Words \\ Creatine $\bullet$ CreaT $\bullet \beta$-glucuronidase $\cdot \mathrm{DSAL} \cdot$ Brain
}

\begin{abstract}
Background/Aims: The transmembrane Klotho protein contributes to inhibition of $1,25(\mathrm{OH})_{2} \mathrm{D}_{3}$ formation. The extracellular domain of Klotho protein could function as an enzyme with e.g. $\beta$-glucuronidase activity, be cleaved off and be released into blood and cerebrospinal fluid. Klotho regulates several cellular transporters. Klotho protein deficiency accelerates the appearance of age related disorders including neurodegeneration and muscle wasting and eventually leads to premature death. The main site of Klotho protein expression is the kidney. Klotho protein is also appreciably expressed in other tissues including chorioid plexus. The present study explored the effect of Klotho protein on the creatine transporter CreaT (SIc6A8), which participates in the maintenance of neuronal function and survival. Methods: To this end cRNA encoding Slc6A8 was injected into Xenopus oocytes with and without additional injection of cRNA encoding Klotho protein. Creatine transporter CreaT (SIc6A8) activity was estimated from creatine induced current determined by two-electrode voltage-clamp. Results: Coexpression of Klotho protein significantly increased creatine-induced current in Slc6A8 expressing Xenopus oocytes. Coexpression of Klotho protein delayed the decline of creatine induced current following inhibition of carrier insertion into the cell membrane by brefeldin A $(5 \mu \mathrm{M})$. The increase of creatine induced current by coexpression of Klotho protein in Slc6A8 expressing Xenopus oocytes was reversed by $\beta$-glucuronidase inhibitor (DSAL). Similarly, treatment of Slc6A8 expressing Xenopus oocytes with recombinant human alpha Klotho protein significantly increased creatine induced current. Conclusion: Klotho protein up-regulates
\end{abstract}

A. Almilaji and M. Sopjani contributed equally to this manuscript and thus share first authorship

Florian Lang, MD

Department of Physiology, University of Tübingen, Gmelinstr. 5, D-72076 Tübingen (Germany), Tel. +49-70712972194, Fax +49-7071295618

E-Mail florian.lang@uni-tuebingen.de 


\section{Kidney Blood Pressure Research}

Kidney Blood Press Res 2014;39:516-525

\begin{tabular}{l|l}
\hline DOI: $10.1159 / 000368462$ & C 2014 S. Karger AG, Basel \\
Published onlIne: November 29, 2014 & www.karger.com/kbr
\end{tabular}

Almilaji/Sopjani/Elvira/Borras Cruzado/Dërmaku-Sopjani/Munoz/Warsi/Lang/Lang: Klotho Sensitive Creatine Transport

the activity of creatine transporter CreaT (Slc6A8) by stabilizing the carrier protein in the cell membrane, an effect requiring $\beta$-glucuronidase activity of Klotho protein.

Copyright $\odot 2014$ S. Karger AG, Basel

\section{Introduction}

Klotho is expressed mainly in kidney and choroid plexus [1, 2]. The extracellular domain of the Klotho protein may function as enzyme with $\beta$-glucuronidase activity and, after being cleaved off, as hormone [3-7]. Klotho expression is a decisive determinant of ageing and life span $[8,9]$. As shown in mice, Klotho deficiency leads to severe growth retardation and accelerates the appearance of several age related disorders resulting in shortening the life span to less than 5 months [8]. Conversely, Klotho overexpression extends substantially the life span [8, 9].

Klotho is required for the inhibitory effect of FGF23 on $1 \alpha$-hydroxylase and thus $1,25(\mathrm{OH})_{2} \mathrm{D}_{3}$ formation [2, 9-11]. 1,25(OH) $)_{2} \mathrm{D}_{3}$ stimulates Klotho expression [12] as well as intestinal and renal $\mathrm{Ca}^{2+}$ and phosphate transport $[13,14]$. Lack of Klotho in Klotho-deficient mice $[2,10,11]$ leads to excessive $1,25(\mathrm{OH})_{2} \mathrm{D}_{3}$ formation with increase of plasma $\mathrm{Ca}^{2+}[15]$ and phosphate [14] concentration, vascular calcification [16] and growth deficit [2]. In addition to its influence on $1,25(\mathrm{OH})_{2} \mathrm{D}_{3}$ formation $[2,9-11,17,18]$ and thus $1,25(\mathrm{OH})_{2} \mathrm{D}_{3}$ dependent regulation of $\mathrm{Ca}^{2+}$ and phosphate transport Klotho influences more directly $\mathrm{Ca}^{2+}$ channels [19] and $\mathrm{Na}^{+}$,phosphate cotransport [4, 20]. Moreover, Klotho up-regulates the $\mathrm{Na}^{+} / \mathrm{K}^{+}$ATPase [21], renal outer medullary $\mathrm{K}^{+}$channels ROMK [22] voltage gated channels, KCNQ1/KCNE1 [23] and excitatory amino acid transporters EAAT 3 and EAAT4 [24]. Thus, Klotho exerts some of its effects by regulating transport mechanisms in the cell membrane.

Carriers expressed in both, brain and kidney include the widely expressed creatine transporter CreaT (Slc6A8) [25-28], a member of the $\mathrm{Na}^{+}, \mathrm{Cl}^{-}$coupled transporter superfamily for neurotransmitters (e.g. dopamine, GABA, serotonin and norepinephrine), amino acids (e.g. glycine) [29-31] as well as the organic osmolytes betaine [32] and taurine [33]. Slc6A8 activity is regulated by AMP activated kinase [34], cyclosporine A [35], mTOR [36], serum and glucocorticoid inducible kinase isoforms [37], PIKfyve [38], as well as Src [39], and its expression is increased by growth hormone [40]. Slc6A8 is further regulated by extracellular and cytosolic creatine levels [41, 42].

The present study explored whether Klotho participates in the regulation of creatine transporter CreaT (Slc6A8). To this end, cRNA encoding Slc6A8 was injected into Xenopus oocytes either without or with additional injection of cRNA encoding Klotho. Moreover, Slc6A8 and Klotho expressing Xenopus oocytes were treated with $\beta$-glucuronidase inhibitor DSAL $(10 \mu \mathrm{M})$. To estimate creatine transporter CreaT (Slc6A8) activity, the creatine induced current was determined utilizing dual electrode voltage clamp.

\section{Materials and Methods}

\section{Constructs}

Murine full-length Klotho was subcloned from pCR-XL-TOPO vector (Imagenes, Berlin, Germany) into pSGEM, a Xenopus oocyte expression vector using XhoI - SpeI restriction sites. For generation of cRNA [43, 44] constructs were used encoding Klotho [20] and CreaT (Slc6A8) [30, 45]. The constructs were used for the generation of cRNA as described previously [46-48].

Voltage clamp in Xenopus oocytes

Xenopus oocytes were prepared as previously described $[49,50]$. Xenopus oocytes were injected with DEPC-water and 15 ng cRNA encoding Slc6A8 with or without additional co-injection of 10 ng cRNA encoding Klotho protein on the same day of preparation of the Xenopus oocytes. The oocytes were maintained at $17^{\circ} \mathrm{C}$ in ND96 solution containing: 88.5.mM NaCl, $2 \mathrm{mM} \mathrm{KCl}, 1 \mathrm{mM} \mathrm{MgC1} 1_{2}, 1.8 \mathrm{mM} \mathrm{CaC1}{ }_{2}$, $5 \mathrm{mM}$ HEPES. Tretracycline 


\section{Kidney Blood Pressure Research}

Kidney Blood Press Res 2014;39:516-525

\begin{tabular}{l|l}
\hline DOI: $10.1159 / 000368462$ & (c) 2014 S. Karger AG, Basel
\end{tabular}

Published onine: November 29, 2014

www.karger.com/kbr

Almilaji/Sopjani/Elvira/Borras Cruzado/Dërmaku-Sopjani/Munoz/Warsi/Lang/Lang: Klotho Sensitive Creatine Transport

(50 mg/l), Ciprofloxacin (1.6 mg/l), Refobacin (100 mg/l) and Theophylin (90 mg/l) as well as sodium pyruvate $(5 \mathrm{mM})$ were added to the ND96, and the $\mathrm{pH}$ was adjusted to 7.5 by addition of $\mathrm{NaOH}$. The control superfusate (ND96) contained $96 \mathrm{mM} \mathrm{NaCl}, 2 \mathrm{mM} \mathrm{KCl}, 1.8 \mathrm{mM} \mathrm{CaCl}, 1 \mathrm{mM} \mathrm{MgCl}$ and $5 \mathrm{mM}$ HEPES. The $\mathrm{pH}$ was adjusted to 7.4 by addition of $\mathrm{NaOH}[51,52]$. Where indicated, Brefeldin A ( $5 \mu \mathrm{M}$, Sigma), recombinant human alpha Klotho protein (30ng/ml, 5334-KL-R\&D Systems) and D-saccharic acid 1,4-lactone monohydrate (DSAL, $10 \mu \mathrm{M}$, Sigma) were added. All experiments were performed at room temperature (about $22^{\circ} \mathrm{C}$ ) 3-5 days after injection. Pipettes were filled with $3 \mathrm{M} \mathrm{KCl}$ and had resistances of 0.3-3.0 $\mathrm{M} \Omega$. The substrate (creatine) was added to the solutions at a concentration of $2 \mathrm{mM}$ unless otherwise stated. The flow rate of the superfusion was approximately $20 \mathrm{ml} / \mathrm{min}$, and a complete exchange of the solution in the recording bath was reached within about $10 \mathrm{sec}$. Where indicated, brefeldin $\mathrm{A}$ at the concentration of $5 \mu \mathrm{M}$ was added to the solutions in order to test for alterations of CreaT protein stability in the plasma membrane. Brefeldin A is involved in plasma membrane trafficking and the treatment of Xenopus oocytes with brefeldin A prevents further insertion of new carrier protein into the plasma membrane through the vesicular pathway. Therefore, the consequent decay of carrier activity could be taken as a measure of carrier protein clearance from the plasma membrane. Two-electrode voltage-clamp recordings were performed as described previously $[53,54]$ at a holding potential of $-60 \mathrm{mV}$. The data were filtered at $10 \mathrm{~Hz}$ and recorded with a GeneClamp 500 amplifier, a DigiData 1300 A/D-D/A converter and the pClamp 9.2 software packages for data acquisition and analysis (Axon Instruments, Foster City, CA, USA) [53, 55]. The offset potentials between both electrodes were zeroed before sealing. The applied voltages refer to the cytoplasmic face of the membrane with respect to the extracellular space. The outward currents, defined as flow of positive charge from the cytoplasmic to the extracellular membrane face, are positive currents and depicted as upward deflections of the original current traces.

\section{Statistical analysis}

Data are provided as means \pm SEM, $n$ represents the number of experiments. All oocyte experiments were repeated with at least 2 batches of oocytes; in all repetitions qualitatively similar data were obtained. Data were tested for significance using ANOVA, as appropriate, and results with $\mathrm{p}<0.05$ were considered statistically significant.

\section{Results}

The present study explored whether Klotho protein participates in the regulation of the $\mathrm{Na}^{+}$-Cl-coupled creatine transporter CreaT (Slc6A8). To this end, cRNA encoding Slc6A8 was injected into Xenopus oocytes with or without additional injection of cRNA encoding Klotho protein. The Slc6A8 activity was estimated from the creatine induced current generated by electrogenic creatine transport. As shown in Fig. 1, creatine did not generate an appreciable current in water-injected Xenopus oocytes or in oocytes expressing Klotho protein alone, indicating that Xenopus oocytes do not express appreciable endogenous electrogenic creatine transporters. In contrast, creatine induced a large current in Xenopus oocytes expressing Slc6A8. The additional coexpression of Klotho was followed by a significant increase of the creatine induced current (Fig. 1).

In order to elucidate whether Klotho protein coexpression modifies the maximal creatine induced current or the affinity of the carrier, Xenopus oocytes expressing Slc6A8 without or with additional expression of Klotho protein were exposed to different concentrations of creatine for kinetic analysis. As shown in Fig. 2, the creatine induced current was a function of the extracellular creatine concentration. The maximal creatine induced current was higher in Xenopus oocytes expressing Slc6A8 together with Klotho $(29.5 \pm 3.5 \mathrm{nA}, \mathrm{n}=8)$ than in Xenopus oocytes expressing Slc6A8 alone $(20.2 \pm 3.7 \mathrm{nA}, \mathrm{n}=10)$. The concentration required for halfmaximal creatine induced current was not significantly different between Xenopus oocytes expressing Slc6A8 together with Klotho $(37.4 \pm 9.0 \mu \mathrm{M}, \mathrm{n}=10)$ and Xenopus oocytes expressing Slc6A8 alone $(34.4 \pm 8.3 \mu \mathrm{M}, \mathrm{n}=8)$. The increased maximal transport rate pointed to an increase of creatine transporter CreaT abundance in the plasma membrane of Scl6A8 expressing Xenopus oocytes following coexpression of Klotho. 


\section{Kidney Blood Pressure Research}

Fig. 1. Effect of Klotho coexpression on electrogenic creatine transport in Slc6A8-expressing Xenopus oocytes. A: Representative original tracings of creatine $(2 \mathrm{mM})$ induced current in Xenopus oocytes injected with water (a), or with cRNA encoding Klotho alone (b),

\section{A}

(a)

(b)

(c)

(d)

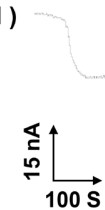

B

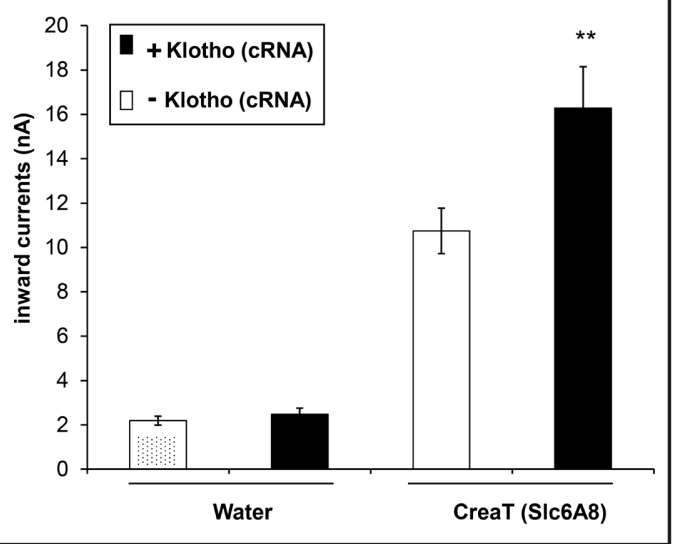

CreaT (Slc6A8) alone (c) or CreaT (Slc6A8) and Klotho (d). B: Arithmetic means \pm SEM ( $\mathrm{n}=19-30)$ of creatine (2 mM) -induced current in Xenopus oocytes without (left bars, - CreaT) or with (right bars, + CreaT) injection of cRNA encoding CreaT (Slc6A8) without (white bars) or with (black bars) additional injection of cRNA encoding Klotho. ${ }^{* *}(\mathrm{p}<0.01)$ indicates statistically significant difference from the absence of Klotho coexpression.

Fig. 2. Creatine induced currents as a function of creatine concentration in Slc6A8 expressing oocytes. Arithmetic means \pm SEM $(n=$ 8-10) of creatine induced current as a function of creatine concentration in Xenopus oocytes expressing CreaT (Slc6A8) without (black triangless) and with (black circles) additional coexpression of Klotho.

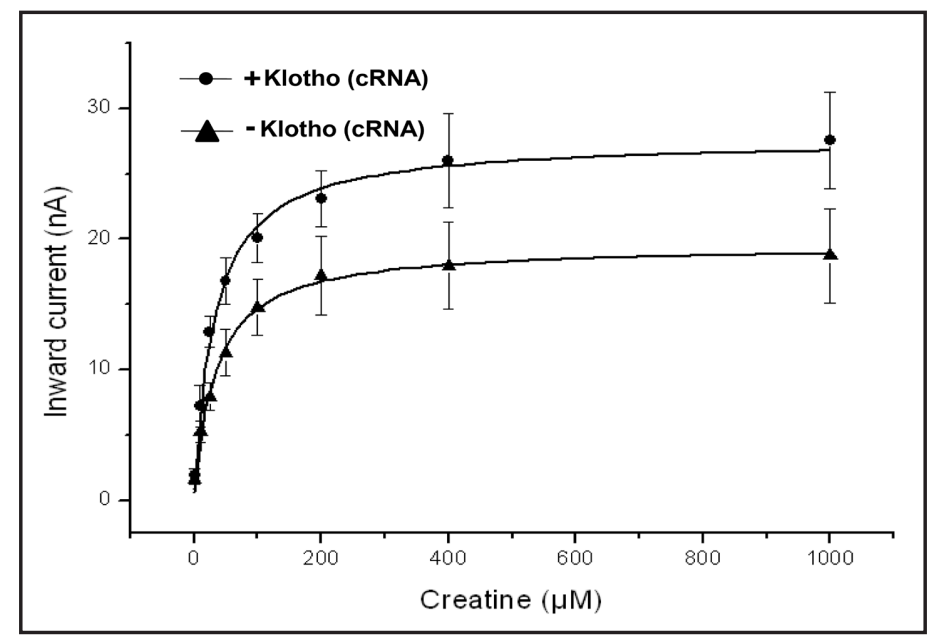

In theory, Klotho could modify carrier protein abundance in the cell membrane by either, accelerating insertion of carrier protein into the cell membrane or delaying retrieval of carrier protein from the cell membrane. In order to discriminate between those two possibilities, Xenopus oocytes expressing either both, Slc6A8 and Klotho, or Slc6A8 alone, were treated with brefeldin A $(5 \mu \mathrm{M})$, an inhibitor of protein insertion into the cell membrane. As shown in Fig. 3, brefeldin A treatment was followed by a decay of the current in both groups, an effect, which was faster in Xenopus oocytes expressing Slc6A8 alone than in Xenopus oocytes expressing both Slc6A8 and Klotho. The ratio of the decay of creatine induced current in Slc6A8 and Klotho expressing Xenopus oocytes over the current in Xenopus oocytes expressing Slc6A8 alone, increased from $0.96 \pm 0.40(n=11)$ in the absence of brefeldin A to $2.01 \pm 0.57(n=11)$ following a 12 hours treatment with brefeldin A. The observations disclose an effect of klotho in the absence of carrier insertion and thus strongly suggest that the effect of klotho is secondary to stabilization of carrier protein within the cell membrane. A further series of experiments elucidated whether the $\beta$-glucuronidase activity of Klotho is required for its effect on Slc6A8 activity. To this end, Xenopus oocytes expressing both, Slc6A8 and Klotho were treated with $\beta$-glucuronidase inhibitor DSAL $(10 \mu \mathrm{M})$ for $48 \mathrm{~h}$ 


\section{Kidney Blood Pressure Research}

Fig. 3. Effect of brefeldin A in Slc6A8 expressing Xenopus oocytes with or without coexpression of Klotho. Arithmetic means \pm SEM ( $n=10-18)$ of the normalized creatine (2 $\mathrm{mM}$ ) induced current in Xenopus oocytes injected with cRNA enconding CreaT, without (white bars) or with additional expression of Klotho (black bars) in the absence (left bars) and presence of $5 \mu \mathrm{M}$ Brefeldin A for 12 hours (middle bars) or 24 hours (right bars) prior to the measurement. * $(\mathrm{p}<0.05),{ }^{* *}(\mathrm{p}<0.005),{ }^{* * *}$ $(p<0.001)$ indicates statistically significant difference from the absence of Klotho coexpression.
Kidney Blood Press Res 2014;39:516-525

\begin{tabular}{l|l}
\hline DOI: $10.1159 / 000368462$ & (c) 2014 S. Karger AG, Basel
\end{tabular}

Publisned ontIne: November 29, 2014

www.karger.com/kbr

Almilaji/Sopjani/Elvira/Borras Cruzado/Dërmaku-Sopjani/Munoz/Warsi/Lang/Lang: Klotho Sensitive Creatine Transport
Fig. 4. Effect of $\beta$-glucuronidase inhibitor (DSAL) and recombinant human alpha Klotho protein on electrogenic creatine transporter CreaT (Slc6A8). A: Arithmetic means \pm SEM $(n=11-18)$ of the normalized creatine (2 $\mathrm{mM})$ induced current in Xenopus oocytes expressing Slc6A8 alone (white bar) or Slc6A8 together with Klotho without ( $1^{\text {st }}$ black bar) and with $\left(2^{\text {nd }}\right.$ black bar $)$ treatment with $\beta$-glucuronidase inhibitor DSAL $(10 \mu \mathrm{M})$ for 48 hours . $*(p<0.05)$ indicates statistically significant difference from respective oocytes expressing Slc6A8 alone, \#(p<0.05), indicates statistically significant difference from Slc6A8 and Klotho expressing oocytes without DSAL treatment. B: Arithmetic means \pm SEM $(n=15-18)$ of the normalized creatine $(2 \mathrm{mM})$ induced current in Xenopus oocytes expressing Slc6A8 alone (white bar) or in Xenopus oocytes injected with cRNA encoding Slc6A8 alone with pretreatment for 24 hours ( $1^{\text {st }}$ black bar) or 48 hours ( $2^{\text {nd }}$ black bar), respectively, with recombinant human alpha Klotho protein $(30 \mathrm{ng} / \mathrm{ml}) .{ }^{*}(\mathrm{p}<0.05),{ }^{* * *}(\mathrm{p}<0.001)$ indicates statistically significant difference from respective oocytes expressing Slc6A8 alone.

in order to suppress $\beta$-glucuronidase activity of expressed klotho. As shown in Fig. 4A, the treatment of Slc6A8 and Klotho-expressing Xenopus oocytes with DSAL reversed the effect of Klotho coexpression on the creatine induced inward current.

Additional experiments were performed to test, whether the effect of Klotho coexpression on creatine induced current was mimicked by treatment of Slc6A8-expressing Xenopus oocytes with recombinant human alpha Klotho protein $(30 \mathrm{ng} / \mathrm{ml}$ ). To possibly disclose a stabilizing effect of klotho on the carrier protein in the cell membrane, the oocytes were exposed for $24 \mathrm{~h}$ or $48 \mathrm{~h}$ to klotho protein. As shown in Fig. 4B, treatment of Slc6A8 expressing Xenopus oocytes with recombinant human alpha Klotho protein resulted in a significant increase of creatine induced inward current. 


\section{Kidney \\ Blood Pressure Research}

Kidney Blood Press Res 2014;39:516-525

\begin{tabular}{l|l}
\hline DOI: $10.1159 / 000368462$ & (C) 2014 S. Karger AG, Basel
\end{tabular}

Publisnea onIIne: November 29, 2014

www.karger.com/kbr

Almilaji/Sopjani/Elvira/Borras Cruzado/Dërmaku-Sopjani/Munoz/Warsi/Lang/Lang: Klotho Sensitive Creatine Transport

\section{Discussion}

The present observations disclose a novel function of Klotho, i.e. the up-regulation of the creatine transporter CreaT (Slc6A8). Klotho increases the maximal transport rate of the carrier presumably by stabilizing the carrier protein in the cell membrane. The Klotho concentration required was within the range of concetrantions encountered in vivo [56]. The effect of Klotho was reversed in the presence of the $\beta$-glucuronidase inhibitor DSAL added from the beginning of Klotho expression in order to continuously suppress $\beta$-glucuronidase activity of expressed Klotho. The reversal of the effect of Klotho indicates that the effect of Klotho on Slc6A8 indeed requires $\beta$-glucuronidase activity of Klotho. Previous studies suggested that Klotho may regulate ion channels by removing terminal sialic acids [5, 6].

Klotho further up-regulates the $\mathrm{Na}^{+} / \mathrm{K}^{+}$ATPase [21], which maintains the electrochemical gradient for $\mathrm{Na}^{+}$coupled transport [57]. Thus, Klotho could modify $\mathrm{Na}^{+}$coupled creatine transport in part by up-regulation of $\mathrm{Na}^{+}, \mathrm{K}^{+}$ATPase activity. The $\mathrm{Na}^{+} / \mathrm{K}^{+}$ATPase further maintains the intracellular $\mathrm{K}^{+}$concentration, which is in turn decisive for cell survival [58-62].

Slc6A8 is critically important for proper function of the brain, as genetic defects of Slc6A8 lead to mental retardation with seizures [63-80]. Slc6A8 deficient mice suffer from learning and memory deficits resembling human Slc6A8 deficiency [63]. Consequences of Klotho deficiency include degeneration of mesencephalic dopaminergic neurons [81], an effect, however, reversed by vitamin D restriction [81] and thus presumably not due to direct influence of Klotho on Slc6A8. Klotho deficiency further leads to cognitive deficits [82]. Klotho is required for proper maturation of rat primary oligodendrocytic progenitor cells [82] and Klotho deficiency is paralleled by lack of oligodendrocytes with decreased abundance of major myelin protein [82]. Downregulation of Klotho in the aged brain may contribute to a decrease of white matter and myelin abnormalities during cerebral ageing [83]. To which extent compromised up-regulation of Slc6A8 by Klotho contributes to the deterioration of cerebral function in Klotho deficiency or in the aging brain, remains to be shown. Clearly, additional studies will be required to define the in vivo relevance of Klotho sensitive creatine transport.

Klotho confers cardioprotection [84], an effect in large part due to down-regulation of TRPC6 channels. It is noteworthy, however, that Slc6A8 deficiency may impair cardiac function [85] and that decreased Slc6A8 abundance is observed in the failing heart [86]. Thus, at least in theory, up-regulation of Slc6A8 could contribute to cardioprotection.

\section{Conclusion}

The present study demonstrates that Klotho is a powerful stimulator of the creatine transporter CreaT (Slc6A8). Klotho dependent regulation of Slc6A8 may contribute to neurodegeneration and cardiac failure in Klotho deficiency.

\section{Disclosure Statement}

The authors of this manuscript state that they do not have any conflict of interests and nothing to disclose.

\section{Acknowledgements}

The authors acknowledge the technical assistance of E. Faber. The manuscript was meticulously prepared by Tanja Loch and Ali Soleimanpour. This study was supported by the Deutsche Forschungsgemeinschaft (GK 1302) and the Open Access Publishing Fund of Tuebingen University. 


\section{Kidney \\ Blood Pressure Research}

Almilaji/Sopjani/Elvira/Borras Cruzado/Dërmaku-Sopjani/Munoz/Warsi/Lang/Lang: Klotho Sensitive Creatine Transport

\section{References}

1 Takeshita K, Fujimori T, Kurotaki Y, Honjo H, Tsujikawa H, Yasui K, Lee JK, Kamiya K, Kitaichi K, Yamamoto K, Ito M, Kondo T, Iino S, Inden Y, Hirai M, Murohara T, Kodama I, Nabeshima Y: Sinoatrial node dysfunction and early unexpected death of mice with a defect of klotho gene expression. Circulation 2004;109:17761782.

2 Tsujikawa H, Kurotaki Y, Fujimori T, Fukuda K, Nabeshima Y: Klotho, a gene related to a syndrome resembling human premature aging, functions in a negative regulatory circuit of vitamin $\mathrm{D}$ endocrine system. Mol Endocrinol 2003;17:2393-2403.

- Imura A, Iwano A, Tohyama O, Tsuji Y, Nozaki K, Hashimoto N, Fujimori T, Nabeshima Y: Secreted Klotho protein in sera and CSF: implication for post-translational cleavage in release of Klotho protein from cell membrane. FEBS Lett 2004;565:143-147.

-4 Hu MC, Shi M, Zhang J, Pastor J, Nakatani T, Lanske B, Razzaque MS, Rosenblatt KP, Baum MG, Kuro-o M, Moe OW: Klotho: a novel phosphaturic substance acting as an autocrine enzyme in the renal proximal tubule. FASEB J 2010;24:3438-3450.

5 Cha SK, Ortega B, Kurosu H, Rosenblatt KP, Kuro OM, Huang CL: Removal of sialic acid involving Klotho causes cell-surface retention of TRPV 5 channel via binding to galectin-1. Proc Natl Acad Sci USA 2008;105:9805-9810.

6 Leunissen EH, Nair AV, Bull C, Lefeber DJ, van Delft FL, Bindels RJ, Hoenderop JG: The epithelial calcium channel TRPV5 is regulated differentially by klotho and sialidase. J Biol Chem 2013;288:29238-29246.

7 Tohyama O, Imura A, Iwano A, Freund JN, Henrissat B, Fujimori T, Nabeshima Y: Klotho is a novel betaglucuronidase capable of hydrolyzing steroid beta-glucuronides. J Biol Chem 2004;279:9777-9784.

8 Kuro-o M, Matsumura Y, Aizawa H, Kawaguchi H, Suga T, Utsugi T, Ohyama Y, Kurabayashi M, Kaname T, Kume E, Iwasaki H, Iida A, Shiraki-Iida T, Nishikawa S, Nagai R, Nabeshima YI: Mutation of the mouse klotho gene leads to a syndrome resembling ageing. Nature 1997;390:45-51.

- Kuro-o M: Klotho. Pflugers Arch 2010;459:333-343.

-10 Razzaque MS, Sitara D, Taguchi T, St Arnaud R, Lanske B: Premature aging-like phenotype in fibroblast growth factor 23 null mice is a vitamin D-mediated process. FASEB J 2006;20:720-722.

11 Yoshida T, Fujimori T, Nabeshima Y: Mediation of unusually high concentrations of 1,25-dihydroxyvitamin D in homozygous klotho mutant mice by increased expression of renal 1alpha-hydroxylase gene. Endocrinology 2002;143:683-689.

12 Alesutan I, Feger M, Pakladok T, Mia S, Ahmed MS, Voelkl J, Lang F: 25-Hydroxyvitamin D3 1-alphahydroxylase-dependent stimulation of renal klotho expression by spironolactone. Kidney Blood Press Res 2013;37:475-487.

13 Ramasamy I: Recent advances in physiological calcium homeostasis. Clin Chem Lab Med 2006;44:237-273.

14 Segawa H, Yamanaka S, Ohno Y, Onitsuka A, Shiozawa K, Aranami F, Furutani J, Tomoe Y, Ito M, Kuwahata M, Imura A, Nabeshima Y, Miyamoto K: Correlation between hyperphosphatemia and type II Na-Pi cotransporter activity in klotho mice. Am J Physiol Renal Physiol 2007;292:F769-F779.

15 Kuro-o M: Klotho as a regulator of fibroblast growth factor signaling and phosphate/calcium metabolism. Curr Opin Nephrol Hypertens 2006;15:437-441.

16 Ohnishi M, Nakatani T, Lanske B, Razzaque MS: Reversal of mineral ion homeostasis and soft-tissue calcification of klotho knockout mice by deletion of vitamin D 1alpha-hydroxylase. Kidney Int 2009;75:1166-1172.

17 Abed M, Feger M, Alzoubi K, Pakladok T, Frauenfeld L, Geiger C, Towhid ST, Lang F: Sensitization of erythrocytes to suicidal erythrocyte death following water deprivation. Kidney Blood Press Res 2013;37:567-578.

-18 Feger M, Fajol A, Lebedeva A, Meissner A, Michael D, Voelkl J, Alesutan I, Schleicher E, Reichetzeder C, Hocher B, Qadri SM, Lang F: Effect of carbon monoxide donor CORM-2 on vitamin D3 metabolism. Kidney Blood Press Res 2013;37:496-505.

19 Boros S, Bindels RJ, Hoenderop JG: Active $\mathrm{Ca}^{2+}$ reabsorption in the connecting tubule. Pflugers Arch 2009;458:99-109.

20 Dermaku-Sopjani M, Sopjani M, Saxena A, Shojaiefard M, Bogatikov E, Alesutan I, Eichenmuller M, Lang F: Downregulation of NaPi-IIa and NaPi-Ilb Na-coupled phosphate transporters by coexpression of Klotho. Cell Physiol Biochem 2011;28:251-258. 


\section{Kidney \\ Blood Pressure Research}

Kidney Blood Press Res 2014;39:516-525

\begin{tabular}{l|l}
\hline DOI: $10.1159 / 000368462$ & $\begin{array}{l}\text { C 2014 S. Karger AG, Basel } \\
\text { www.karger.com/kbr }\end{array}$ \\
\hline
\end{tabular}

Almilaji/Sopjani/Elvira/Borras Cruzado/Dërmaku-Sopjani/Munoz/Warsi/Lang/Lang: Klotho Sensitive Creatine Transport

-21 Sopjani M, Alesutan I, Dermaku-Sopjani M, Gu S, Zelenak C, Munoz C, Velic A, Foller M, Rosenblatt KP, Kuro-o M, Lang F: Regulation of the Na+/K+ ATPase by Klotho. FEBS Lett 2011;585:1759-1764.

22 Cha SK, Hu MC, Kurosu H, M K-o, Moe O, Huang CL: Regulation of renal outer medullary potassium channel and renal K(+) excretion by Klotho. Mol Pharmacol 2009;76:38-46.

-23 Almilaji A, Pakladok T, Munoz C, Elvira B, Sopjani M, Lang F: Upregulation of KCNQ1/KCNE1 K channels by Klotho. Channels (Austin) 2014;8: in press.

24 Almilaji A, Munoz C, Pakladok T, Alesutan I, Feger M, Foller M, Lang UE, Shumilina E, Lang F: Klotho sensitivity of the neuronal excitatory amino acid transporters EAAT3 and EAAT4. PLoS One 2013;8:e70988.

-25 Braissant 0, Henry H: AGAT, GAMT and SLC6A8 distribution in the central nervous system, in relation to creatine deficiency syndromes: a review. J Inherit Metab Dis 2008;31:230-239.

26 Guimbal C, Kilimann MW: A Na(+)-dependent creatine transporter in rabbit brain, muscle, heart, and kidney. cDNA cloning and functional expression. J Biol Chem 1993;268:8418-8421.

-27 Mak CS, Waldvogel HJ, Dodd JR, Gilbert RT, Lowe MT, Birch NP, Faull RL, Christie DL: Immunohistochemical localisation of the creatine transporter in the rat brain. Neuroscience 2009;163:571-585.

28 Mellott TJ, Kowall NW, Lopez-Coviella I, Blusztajn JK: Prenatal choline deficiency increases choline transporter expression in the septum and hippocampus during postnatal development and in adulthood in rats. Brain Res 2007;1151:1-11.

29 Christie DL: Functional insights into the creatine transporter. Subcell Biochem 2007;46:99-118.

-30 Dodd JR, Christie DL: Cysteine 144 in the third transmembrane domain of the creatine transporter is located close to a substrate-binding site. J Biol Chem 2001;276:46983-46988.

-31 Sora I, Richman J, Santoro G, Wei H, Wang Y, Vanderah T, Horvath R, Nguyen M, Waite S, Roeske WR, . The cloning and expression of a human creatine transporter. Biochem Biophys Res Commun 1994;204:419427.

-32 Takenaka M, Bagnasco SM, Preston AS, Uchida S, Yamauchi A, Kwon HM, Handler JS: The canine betaine gamma-amino-n-butyric acid transporter gene: diverse mRNA isoforms are regulated by hypertonicity and are expressed in a tissue-specific manner. Proc Natl Acad Sci USA 1995;92:1072-1076.

-33 Uchida S, Kwon HM, Yamauchi A, Preston AS, Marumo F, Handler JS: Molecular cloning of the cDNA for an MDCK cell $\mathrm{Na}(+)$ - and $\mathrm{Cl}(-)$-dependent taurine transporter that is regulated by hypertonicity. Proc Natl Acad Sci USA 1992;89:8230-8234.

34 Li H, Thali RF, Smolak C, Gong F, Alzamora R, Wallimann T, Scholz R, Pastor-Soler NM, Neumann D, Hallows KR: Regulation of the creatine transporter by AMP-activated protein kinase in kidney epithelial cells. Am J Physiol Renal Physiol 2010;299:F167-F177.

35 Tran TT, Dai W, Sarkar HK: Cyclosporin A inhibits creatine uptake by altering surface expression of the creatine transporter. J Biol Chem 2000;275:35708-35714.

-36 Shojaiefard M, Christie DL, Lang F: Stimulation of the creatine transporter SLC6A8 by the protein kinase mTOR. Biochem Biophys Res Commun 2006;341:945-949.

-37 Shojaiefard M, Christie DL, Lang F: Stimulation of the creatine transporter SLC6A8 by the protein kinases SGK1 and SGK3. Biochem Biophys Res Commun 2005;334:742-746.

-38 Strutz-Seebohm N, Shojaiefard M, Christie D, Tavare J, Seebohm G, Lang F: PIKfyve in the SGK1 mediated regulation of the creatine transporter SLC6A8. Cell Physiol Biochem 2007;20:729-734.

39 Wang W, Jobst MA, Bell B, Zhao CR, Shang LH, Jacobs DO: Cr supplementation decreases tyrosine phosphorylation of the CreaT in skeletal muscle during sepsis. Am J Physiol Endocrinol Metab 2002;282:E1046-E1054.

40 Omerovic E, Bollano E, Lorentzon M, Walser M, Mattsson-Hulten L, Isgaard J: Growth hormone induces myocardial expression of creatine transporter and decreases plasma levels of IL-1beta in rats during early postinfarct cardiac remodeling. Growth Horm IGF Res 2003;13:239-245.

41 Brault JJ, Abraham KA, Terjung RL: Muscle creatine uptake and creatine transporter expression in response to creatine supplementation and depletion. J Appl Physiol 2003;94:2173-2180.

42 Loike JD, Zalutsky DL, Kaback E, Miranda AF, Silverstein SC: Extracellular creatine regulates creatine transport in rat and human muscle cells. Proc Natl Acad Sci USA 1988;85:807-811.

-43 Alesutan I, Sopjani M, Dermaku-Sopjani M, Munoz C, Voelkl J, Lang F: Upregulation of Na-coupled glucose transporter SGLT1 by Tau tubulin kinase 2. Cell Physiol Biochem 2012;30:458-465. 


\section{Kidney \\ Blood Pressure Research}

Kidney Blood Press Res 2014;39:516-525

\begin{tabular}{l|l}
\hline DOI: $10.1159 / 000368462$ & C 2014 S. Karger AG, Basel
\end{tabular}

Published onIIne: November 29, 2014

www.karger.com/kbr Klotho Sensitive Creatine Transport

44 Henrion U, Zumhagen S, Steinke K, Strutz-Seebohm N, Stallmeyer B, Lang F, Schulze-Bahr E, Seebohm G: Overlapping cardiac phenotype associated with a familial mutation in the voltage sensor of the KCNQ1 channel. Cell Physiol Biochem 2012;29:809-818.

45 Shojaiefard M, Hosseinzadeh Z, Bhavsar SK, Lang F: Downregulation of the creatine transporter SLC6A8 by JAK2. J Membr Biol 2012;245:157-163.

-46 Almilaji A, Munoz C, Hosseinzadeh Z, Lang F: Upregulation of Na+,Cl(-)-coupled betaine/gamma-aminobutyric acid transporter BGT1 by Tau tubulin kinase 2. Cell Physiol Biochem 2013;32:334-343.

-47 Almilaji A, Szteyn K, Fein E, Pakladok T, Munoz C, Elvira B, Towhid ST, Alesutan I, Shumilina E, Bock CT, Kandolf R, Lang F: Down-regulation of Na/K+ atpase activity by human parvovirus B19 capsid protein VP1. Cell Physiol Biochem 2013;31:638-648.

-48 Dermaku-Sopjani M, Almilaji A, Pakladok T, Munoz C, Hosseinzadeh Z, Blecua M, Sopjani M, Lang F: Downregulation of the Na+-coupled phosphate transporter NaPi-IIa by AMP-activated protein kinase. Kidney Blood Press Res 2013;37:547-556.

49 Hosseinzadeh Z, Bhavsar SK, Lang F: Downregulation of ClC-2 by JAK2. Cell Physiol Biochem 2012;29:737742.

50 Bogatikov E, Munoz C, Pakladok T, Alesutan I, Shojaiefard M, Seebohm G, Foller M, Palmada M, Bohmer C, Broer S, Lang F: Up-regulation of amino acid transporter SLC6A19 activity and surface protein abundance by PKB/Akt and PIKfyve. Cell Physiol Biochem 2012;30:1538-1546.

51 Pathare G, Foller M, Daryadel A, Mutig K, Bogatikov E, Fajol A, Almilaji A, Michael D, Stange G, Voelkl J, Wagner CA, Bachmann S, Lang F: OSR1-Sensitive Renal Tubular Phosphate Reabsorption. Kidney Blood Press Res 2012;36:149-161.

52 Pakladok T, Almilaji A, Munoz C, Alesutan I, Lang F: PIKfyve sensitivity of hERG channels. Cell Physiol Biochem 2013;31:785-794.

53 Mia S, Munoz C, Pakladok T, Siraskar G, Voelkl J, Alesutan I, Lang F: Downregulation of Kv1.5 K Channels by the AMP-Activated Protein Kinase. Cell Physiol Biochem 2012;30:1039-1050.

54 Hosseinzadeh Z, Dong L, Bhavsar SK, Warsi J, Almilaji A, Lang F: Upregulation of peptide transporters PEPT1 and PEPT2 by Janus kinase JAK2. Cell Physiol Biochem 2013;31:673-682.

55 Hosseinzadeh Z, Bhavsar SK, Lang F: Down-regulation of the myoinositol transporter SMIT by JAK2. Cell Physiol Biochem 2012;30:1473-1480.

56 Devaraj S, Syed B, Chien A, Jialal I: Validation of an immunoassay for soluble Klotho protein: decreased levels in diabetes and increased levels in chronic kidney disease. Am J Clin Pathol 2012;137:479-485.

57 Lang F, Rehwald W: Potassium channels in renal epithelial transport regulation. Physiol Rev 1992;72:1-32.

58 Becker S, Reinehr R, Graf D, vom DS, Haussinger D: Hydrophobic bile salts induce hepatocyte shrinkage via NADPH oxidase activation. Cell Physiol Biochem 2007;19:89-98.

59 Bortner CD, Cidlowski JA: The role of apoptotic volume decrease and ionic homeostasis in the activation and repression of apoptosis. Pflugers Arch 2004;448:313-318.

-60 Foller M, Kasinathan RS, Duranton C, Wieder T, Huber SM, Lang F: PGE2-induced apoptotic cell death in K562 human leukaemia cells. Cell Physiol Biochem 2006;17:201-210.

-61 Schneider J, Nicolay JP, Foller M, Wieder T, Lang F: Suicidal erythrocyte death following cellular $\mathrm{K}^{+}$loss. Cell Physiol Biochem 2007;20:35-44.

62 Shimizu T, Wehner F, Okada Y: Inhibition of hypertonicity-induced cation channels sensitizes HeLa cells to shrinkage-induced apoptosis. Cell Physiol Biochem 2006;18:295-302.

63 Skelton MR, Schaefer TL, Graham DL, Degrauw TJ, Clark JF, Williams MT, Vorhees CV: Creatine transporter (CrT; Slc6a8) knockout mice as a model of human CrT deficiency. PLoS One 2011;6:e16187.

64 Alcaide P, Rodriguez-Pombo P, Ruiz-Sala P, Ferrer I, Castro P, Ruiz MY, Merinero B, Ugarte M: A new case of creatine transporter deficiency associated with mild clinical phenotype and a novel mutation in the SLC6A8 gene. Dev Med Child Neurol 2010;52:215-217.

65 Alcaide P, Merinero B, Ruiz-Sala P, Richard E, Navarrete R, Arias A, Ribes A, Artuch R, Campistol J, Ugarte M, Rodriguez-Pombo P: Defining the pathogenicity of creatine deficiency syndrome. Hum Mutat 2011;32:282291.

-66 Ardon O, Amat di San FC, Salomons GS, Longo N: Creatine transporter deficiency in two half-brothers. Am J Med Genet A 2010;152A:1979-1983. 


\section{Kidney \\ Blood Pressure Research}

Kidney Blood Press Res 2014;39:516-525

\begin{tabular}{l|l}
\hline DOI: $10.1159 / 000368462$ & (c) 2014 S. Karger AG, Basel
\end{tabular}

Publisned ontıne: November 29, 2014

www.karger.com/kbr

Amilaji/Sopjani/Elvira/Borras Cruzado/Dërmaku-Sopjani/Munoz/Warsi/Lang/Lang: Klotho Sensitive Creatine Transport

67 Battini R, Chilosi A, Mei D, Casarano M, Alessandri MG, Leuzzi V, Ferretti G, Tosetti M, Bianchi MC, Cioni G: Mental retardation and verbal dyspraxia in a new patient with de novo creatine transporter (SLC6A8) mutation. Am J Med Genet A 2007;143A:1771-1774.

68 Battini R, Chilosi AM, Casarano M, Moro F, Comparini A, Alessandri MG, Leuzzi V, Tosetti M, Cioni G: Language disorder with mild intellectual disability in a child affected by a novel mutation of SLC6A8 gene. Mol Genet Metab 2011;102:153-156.

-69 Braissant O, Beard E, Torrent C, Henry H: Dissociation of AGAT, GAMT and SLC6A8 in CNS: relevance to creatine deficiency syndromes. Neurobiol Dis 2010;37:423-433.

-70 Braissant 0, Henry H, Beard E, Uldry J: Creatine deficiency syndromes and the importance of creatine synthesis in the brain. Amino Acids 2011;40:1315-1324.

-71 Hahn KA, Salomons GS, Tackels-Horne D, Wood TC, Taylor HA, Schroer RJ, Lubs HA, Jakobs C, Olson RL, Holden KR, Stevenson RE, Schwartz CE: X-linked mental retardation with seizures and carrier manifestations is caused by a mutation in the creatine-transporter gene (SLC6A8) located in Xq28. Am J Hum Genet 2002;70:1349-1356.

72 Jensen LR, Chen W, Moser B, Lipkowitz B, Schroeder C, Musante L, Tzschach A, Kalscheuer VM, Meloni I, Raynaud M, van Esch H, Chelly J, de Brouwer AP, Hackett A, van der HS, Henn W, Gecz J, Riess O, Bonin M, Reinhardt R, Ropers HH, Kuss AW: Hybridisation-based resequencing of 17 X-linked intellectual disability genes in 135 patients reveals novel mutations in ATRX, SLC6A8 and PQBP1. Eur J Hum Genet 2011;19:717720.

73 Longo N, Ardon O, Vanzo R, Schwartz E, Pasquali M: Disorders of creatine transport and metabolism. Am J Med Genet C Semin Med Genet 2011;157:72-78.

74 Mancardi MM, Caruso U, Schiaffino MC, Baglietto MG, Rossi A, Battaglia FM, Salomons GS, Jakobs C, Zara F, Veneselli E, Gaggero R: Severe epilepsy in X-linked creatine transporter defect (CRTR-D). Epilepsia 2007;48:1211-1213.

-75 Mercimek-Mahmutoglu S, Connolly MB, Poskitt KJ, Horvath GA, Lowry N, Salomons GS, Casey B, Sinclair G, Davis C, Jakobs C, Stockler-Ipsiroglu S: Treatment of intractable epilepsy in a female with SLC6A8 deficiency. Mol Genet Metab 2010;101:409-412.

-76 Puusepp H, Kall K, Salomons GS, Talvik I, Mannamaa M, Rein R, Jakobs C, Ounap K: The screening of SLC6A8 deficiency among Estonian families with X-linked mental retardation. J Inherit Metab Dis 2010;33:S5-11.

77 Rosenberg EH, Martinez MC, Betsalel OT, van Dooren SJ, Fernandez M, Jakobs C, Degrauw TJ, Kleefstra T, Schwartz CE, Salomons GS: Functional characterization of missense variants in the creatine transporter gene (SLC6A8): improved diagnostic application. Hum Mutat 2007;28:890-896.

78 Salomons GS, van Dooren SJ, Verhoeven NM, Marsden D, Schwartz C, Cecil KM, Degrauw TJ, Jakobs C: X-linked creatine transporter defect: an overview. J Inherit Metab Dis 2003;26:309-318.

79 Stockler S, Schutz PW, Salomons GS: Cerebral creatine deficiency syndromes: clinical aspects, treatment and pathophysiology. Subcell Biochem 2007;46:149-166.

-80 van de Kamp JM, Mancini GM, Pouwels PJ, Betsalel OT, van Dooren SJ, de K, I, Steenweg ME, Jakobs C, van der Knaap MS, Salomons GS: Clinical features and X-inactivation in females heterozygous for creatine transporter defect. Clin Genet 2011;79:264-272.

-81 Kosakai A, Ito D, Nihei Y, Yamashita S, Okada Y, Takahashi K, Suzuki N: Degeneration of mesencephalic dopaminergic neurons in klotho mouse related to vitamin D exposure. Brain Res 2011;1382:109-117.

82 Chen CD, Sloane JA, Li H, Aytan N, Giannaris EL, Zeldich E, Hinman JD, Dedeoglu A, Rosene DL, Bansal R, Luebke JI, Kuro O, Abraham CR: The Antiaging Protein Klotho Enhances Oligodendrocyte Maturation and Myelination of the CNS. J Neurosci 2013;33:1927-1939.

83 Abraham CR, Chen C, Cuny GD, Glicksman MA, Zeldich E: Small-molecule Klotho enhancers as novel treatment of neurodegeneration. Future Med Chem 2012;4:1671-1679.

84 Xie J, Cha SK, An SW, Kuro O, Birnbaumer L, Huang CL: Cardioprotection by Klotho through downregulation of TRPC6 channels in the mouse heart. Nat Commun 2012;3:1238.

85 Anselm IA, Coulter DL, Darras BT: Cardiac manifestations in a child with a novel mutation in creatine transporter gene SLC6A8. Neurology 2008;70:1642-1644.

-86 Neubauer S, Remkes H, Spindler M, Horn M, Wiesmann F, Prestle J, Walzel B, Ertl G, Hasenfuss G, Wallimann $\mathrm{T}$ : Downregulation of the $\mathrm{Na}(+)$-creatine cotransporter in failing human myocardium and in experimental heart failure. Circulation 1999;100:1847-1850. 